\title{
Behavioural Factors in the Hungarian Retail Government Bond Market*
}

\author{
Gábor Kutasi - László György - Krisztina Szabó
}

It has long been known that the decision-making of money market participants deviates from the pattern outlined by textbook models. This study attempts to explore the real processes taking the approach of behavioural finance, and analyses the hypothetical investment decisions of Hungarian retail government bond investors based on the literature of behavioural finance theses. The analysis relies on the results of a representative opinion poll using behavioural finance theory on the government bond market as a basis. The survey covers the political, emotional and literacy factors underlying the decisions. It examines the herding effect, the influence of demographic factors, and as a new approach, it outlines the profile of Hungarian retail investors. One other novel result of the survey is that it confirms a number of commonly known assumptions about the behaviour of retail investors through collecting data, while reviewing and synthesising behavioural finance literature specifically relevant to the government bond market.

Journal of Economic Literature (JEL) codes: D91, G11, G41

Keywords: behavioural finance, government bond, retail investor, non-rational decision-making

\section{Introduction}

Empirically, it was established a long time ago that decisions made in money markets do not follow the patterns outlined by textbook models. The study reveals the behaviour and way of thinking of Hungarian households in the domestic government bond market. According to our initial assumption, the decisions made by households are not solely based on a desire to maximise returns. One novel

\footnotetext{
* The views expressed in this paper are those of the author(s) and do not necessarily reflect the offical view of the Magyar Nemzeti Bank.

Gábor Kutasi (PhD, Dr. habil.) is a former analyst at Századvég Gazdaságkutató Zrt., assistant professor at the MNB Department of Corvinus University of Budapest and researcher of the Magyar Nemzeti Bank; his research activity has been supported by the KÖFOP-2.1.2-VEKOP-15-2016-00001 project. E-mail: gabor.kutasi@uni-corvinus.hu

László György (PhD) is a senior economist at Századvég Gazdaságkutató Zrt., assistant professor at Neumann János University. E-mail: gyorgy@szazadveg.hu

Krisztina Szabó is an assistant lecturer at Corvinus University of Budapest, postgraduate student of the BCE International Relations PhD programme. E-mail: krisztina.szabo11@uni-corvinus.hu

The Hungarian manuscript was received on 21 September 2017.

DOI: http://doi.org/10.25201/FER.17.1.110136
} 
outcome of the study is that it analyses the hypothetical decision-making behaviour of Hungarian retail government bond investors through an opinion poll based on a review of behavioural finance literature relevant to the government bond market.

The survey covers the political, emotional and literacy factors underlying the decisions. Moreover, the herding effect and the influence of demographic factors are also investigated. The relevant literature served as a basis for identifying factors influencing the demand side of the retail government bond market. The study captures how Hungarian retail investors adjust their government bond portfolios in response to international effects, and presumably, the steps of market-shaping investors. It draws conclusions about the extent of non-rational decision-making and excessive risk-taking or risk aversion.

One new result is the profile of Hungarian retail investors outlined by the study. Another novel outcome is that it confirms a number of commonly known assumptions about the behaviour of retail investors through collecting data, while synthesising an overview of the behavioural finance literature that is specifically relevant to the government bond market.

The results are particularly relevant in an economic policy and government-debt strategy environment that favours domestic retail investors purchasing a substantial part of government bonds as opposed to non-resident investors.

\section{Methodology}

The results of behavioural finance so far have demonstrated that the individual and societal characteristics of household investors (e.g. gender, financial standing, age, marital status, etc.) influence savings habits and the composition of the investment portfolio. Accordingly, the interest rate level is not the only factor determining the success and cost of bond management in the government bond market. The survey was guided by the following question: What characteristics shape demand for government bonds among Hungarian households?

The survey adopted the following method:

We collected the determinants of investments and compiled our own questions for the poll on this basis. We conducted two questionnaire-based surveys on a representative sample of Hungarian households with regard to savings habits and risk acceptance. The survey was conducted and the resulting database was compiled by the staff of the Századvég Foundation. As the number of questions exceeded the possibilities of phone polling, the questionnaire-based survey had to be conducted in more than one round. 
The first survey method was as follows: on 18-24 October 2016, we conducted an opinion poll among the adult Hungarian population, during which we polled 2,002 randomly selected adults using the CATI method (Computer Assisted Telephone Interviewing). For sampling reasons the data divulged in the analysis may deviate by no more than \pm 2.2 percentage points from the data that would have been obtained by interviewing the entire adult population of the country.

The second survey method was as follows: on 22-29 October 2016, we conducted an opinion poll among the adult Hungarian population, during which we polled 2,005 randomly selected adults using the CATI method. For sampling reasons the data divulged in the analysis may deviate by no more than \pm 2.2 percentage points from the data that would have obtained by interviewing the entire adult population of the country.

In compiling the household questionnaires, we considered the ideas raised in the studies referred to in the theoretical chapter and in the Legg Mason (2015) presentation. During the survey, we recorded the profiles of the respondents in terms of age, gender, education, residence, self-described social status, political leaning, labour market activity, and number of members in the household.

\section{Behavioural finance in the government bond market}

\subsection{Political instability}

Political risk, owing to the effect of political stability and uncertainty and political realignment at the level of information, may influence the rationality of investors' decisions. In their study, Pantzalis et al. (2000) examined the behaviour of stock market indices across 33 countries around political election dates between 1974 and 1995. They found positive, abnormal returns during the two-week period prior to the election. Their findings are consistent with those of Brown et al. (1988), and Harrington (1993), namely, that elections susceptible to certain political directions are accompanied by greater uncertainty and they are more likely to be manipulated. According to the model, the uncertainties surrounding political elections tend to raise the return on securities.

Moser (2007) attempts to explore the extent to which investors' decisions are affected by the departure - resignation or dismissal - of a country's minister of finance. Examining twelve Latin-American countries, the author found that such political news instantaneously increased bond spreads on the day of the announcement. The subsequent decline in the spread offset the previous hike to some extent, but the weeks following the announcement were characterised by political instability, and the spread flattened out on a higher level than the initial value. Huang et al. (2015) studied the effect of international political risks on government bond yields. The authors investigated 109 international political 
crises on a sample of 34 debtor countries, and found a significant link between international political risks and government bond yields.

\subsection{The emotional factor}

An utter disregard for investor sentiment is typical of classical finance theories. The following studies, however, provide evidence that emotions undoubtedly exert a strong impact on investors' decisions, although the influence of investor sentiment is extremely hard to quantify. Martell (2008) investigated the determinants of the spread between the yields on certain sovereign bonds and US government bonds, and found that even after adjusting for fundamentals motivated by structural credit risk models, there were still significant unexplained components of the yield spread, some of which may be attributed to emotional factors.

Baker and Wurgler (2006) studied how investor sentiment affects stock market securities, and demonstrated - albeit to a different degree in individual cases - that certain emotions (fear, euphoria) have an explanatory power in investors' decisions, although the intensity of their effects may vary. (Several earlier studies had arrived at a similar conclusion: Kothari-Shanken 1997; Neal-Wheatley 1998; Shiller 2000). The analysis by Laborda and Olmo (2014), which was specifically intended to study the relationship between the risk premium on US sovereign bonds and a set of market sentiment variables, is also based on the above study. The authors' findings revealed that the market sentiment factor had predictive power beyond that contained in the yield curve and benchmark macroeconomic factors. However, its predictive power varies over time, exhibiting more relevance during recession periods.

\subsection{Demographic factors}

The study by Sevic and Brawn (2015) attempts to gauge the effect of demographic specificities on government bond yields. The authors compared the inflation-adjusted yield on 10-year government bonds of seven developed countries to a benchmark, to determine the extent to which the low level of the real bond yield can be explained by demographic and non-demographic variables. Modigliani and Brumberg (1954) were pioneers in examining the relationship between the financial market and demographic variables, which can be traced back to the life-cycle hypothesis. The younger generation tends to invest a substantial part of its income in real estate, whereas the older generation is characterised by a propensity to save.

Bakshi and Chen (1994) found that aggregate consumption and demographic fluctuations can, to a certain degree, predict the risk premium. Owing to the ageing society phenomenon, capital typically flows into the securities market rather than the real estate market. Davis and Li (2003) explored the relationship between demographics and financial asset prices in a number of OECD countries. Those aged 40-64 are more likely to hold their savings in real assets and live on the yields, whereas the 65+ generation is strongly linked to bonds and bond yields; the latter 
may be partly attributed to the retirement age and pensions derived from private pension funds, as pension funds can mainly invest in bonds.

Arnott and Chaves (2012) pointed out that the expected return for securities rises for the 40-64 year-old age group, which can partly be explained by age characteristics, since a middle-aged person is typically less likely to avoid uncertainty than an older investor. Accordingly, another conclusion of the study is that the expected return falls for those over 65. Barber and Odean (2001) revealed a relationship between the investor's gender and trading activity. Through psychological testing they demonstrated that men's financial decisions are more likely to be extreme or risky than those of women.

\subsection{Geographical and cultural factors}

Coval and Moskowitz (1999), Kang (1997), as well as Karlsson and Norden (2007) demonstrated that portfolio allocation is strongly influenced by geographical bias. Amadi (2004) concluded that institutional investors' demand for foreign stocks and hence, the diversification of the institutional portfolio, are strongly influenced by certain factors, such as a common language, trade and possibly immigration traditions. According to Kang et al. (2010), the under- or over-valuation of foreign stocks can be explained, on the one hand, by the different evaluation of domestic and foreign investors and, on the other hand, by the home bias exhibited by investors. Ferreira and Matos (2008) found that non-US-based foreign investors often overvalue the stock of US firms. Examining the decisions and behaviour of Finnish investors, Grinblatt and Keloharju (2001) concluded that Finnish investors are more likely to invest in firms that have Finnish management.

According to the investigation of Karlsson and Norden (2007) in Sweden, there is also a relationship between investors' gender and the degree of their home bias. In their empirical analysis, Swedish men proved to be far more biased towards the bonds of their own country than women. Guiso et al. (2004) concluded that perceptions rooted in culture are important determinants of the trust citizens have for the citizens of other countries, which explains investors' behaviour and decisions in the equity market. Beugelsdijk and Frijns (2010) argued that a society's culture and cultural differences play an important role in the diversification of portfolio allocation. Power et al. (2009) stressed the importance of a nation's culture as they compared collectivist, emerging Asian economies with individualistic, industrialised Western nations.

The research conducted by Anderson et al. (2011) covered 60 countries to study the diversification of the institutional portfolio and the effect of cultural factors. Introducing country-specific variables on cross-cultural behaviours, the authors found that behavioural differences between cultures account for the diversification of foreign capital and home bias. It is especially in risk-averse countries that investment funds are more likely to exhibit home bias and hold less diversified 
investments. Culturally distant countries typically invest less abroad; indeed, they are prone to disregard culturally distant target markets. ${ }^{1}$

\section{Behaviour of retail investors in the Hungarian government bond market}

\subsection{Degree of non-rational decision-making}

For this study, the household surveys were designed to capture the presence of investor decisions that are non-rational in the economic sense among Hungarian households, and to assess the magnitude of this phenomenon. Lack of information is one of the criteria of non-rational decision-making. In this regard we asked respondents whether the government guarantees the yields on and the redemption of government bonds. Only 55 per cent of the respondents thought/knew that government bonds are backed by the state's payment guarantee. Although information improved with age, only about 60 per cent of the 40+ age-group was aware of this fact. Education is a stronger determinant of information: 71 per cent of those with higher education knew about the state guarantee. Similarly, higher income - which may be strongly related to education and the ability to save - also brought greater knowledge about investment issues. Compared to the responses given to other questions designed to gauge the level of information, there is a strong relationship between the perception of the riskiness of various investment instruments and the (lack of) knowledge about the state guarantee. More than two thirds of the respondents who considered government bonds the riskiest investment instrument in response to a different question did not know about the state guarantee. 90 per cent of the respondents who considered government bonds the least risky investment option were aware of the state guarantee. Irrational investment decisions stemming from inadequate information can be clearly captured in the responses. Less than 20 per cent of those perceiving government bonds too risky to invest in had heard about the state guarantee.

We detected a degree of interpretational uncertainty in the understanding of investment instruments as well, which may contribute to reducing financial rationality. We asked the respondents to select the least risky instrument from the following list: share, government bond, corporate bond, gold, real estate. Most respondents perceived real estate to be the least risky instrument. Gold was second, and government bonds only came third on the list. In addition, a significant number of the respondents presumably interpreted the safe investment option of gold as

\footnotetext{
${ }^{1}$ The study takes the primary dimensions of cultural attributes identified by Geert Hofstede (2001) as a basis. According to Hofstede, countries' cultural attributes can be measured in five primary dimensions: power distance, individualism versus collectivism, masculinity versus femininity, uncertainty avoidance, longterm versus short-term orientation. According to Hofstede's dimensions, Hungary is a strongly masculine, extremely uncertainty avoiding, strongly individualistic country with a medium-term orientation (pessimistic) that finds it medium-hard to tolerate the centralisation of power (http://geert-hofstede.com/hungary.html). On the whole, it can be called medium-distant in a cultural sense.
} 
an easily mobilised monetary asset that can be physically held by them and used any time as a payment alternative. They disregarded the fact that the price of gold fundamentally hinges on the price quoted on international commodity exchanges and that gold, as an essentially speculative financial instrument, has a continuously fluctuating price. So a certain degree of cognitive dissonance is also evident in this regard. It is not surprising, then, that education has an explanatory power in this case as well. Twice as many respondents with higher education (32\%) perceived government bonds to be the least risky investment instrument than those with primary education (14\%). Income, in this case, also points in the same direction as risk perception. Obviously, this is because those with higher income encounter saving options more often and tend to belong to the more educated segment.

Only 37.3 per cent of the respondents held investments. More than one third of them - 13.1 per cent of the respondents - declared that they do not monitor the status of their investments. Although there are investment schemes that do not require any monitoring on the part of the investor before maturity, this case is more about respondents' lack of motivation to understand the value, composition and maturity of their invested assets, which not only reveals a lack of financial awareness, but also reflects inadequate information, i.e. a non-rational decisionmaking situation.

The survey revealed that 89 per cent of the respondents had no savings in Hungarian sovereign bonds at the time of the interview. 62.2 per cent of the respondents had no savings at all. We asked them the reason why. The distribution of the responses is summarised in Figure 1. It indicates that 5.4 per cent of the respondents do not know the conditions and the risks - i.e. their information is not perfect -, while 7.8 per cent explained their decision specifically with a political motivation. Political opinion strikingly influenced responses: 25 per cent of those describing themselves as left-wing voters declared their reluctance to "loan their money to this government", whereas this rate is around 5 per cent among respondents with a central or right-wing orientation. With respect to age distribution, the rejection on political grounds was the highest among the youngest cohort (12.5\%), whereas the saving rate was relatively low in this age group. Rejection on political grounds is easily the highest among those with higher education (11.3\%), although 9.9 per cent of the respondents with secondary education would also be reluctant to loan money to the government. The rate of political rejection is 10.6 per cent among respondents in the highest income bracket.

Differences in responses by education are aptly reflected in responses by income clusters. Only half of the highest-income group cited their inability to save; 8 per cent mentioned that they did not know the conditions, 10.6 per cent rejected such investments on political grounds; all in all, 24.6 per cent seek investment opportunities in markets other than the government bond market. 
Intention to purchase is perceivably influenced by information. The result of the questions intended to gauge respondents' knowledge - that were included in the same survey as the questions regarding their intention to purchase - is the following: 35 per cent of those - wrongly - believing that government papers are not subject to any tax allowances would not buy sovereign bonds, while this rate is 25 per cent among the respondents that are aware of the tax allowance. 33.5 per cent of those who wrongly - believe that the return on bank deposits exceeds the yield on government bonds would not invest in Hungarian sovereign bonds, while this statement is true for 41.7 per cent of those who perceived - also wrongly - the returns to be identical. The rate of rejection is only 26.3 per cent among respondents who were aware of the fact government bonds have a higher yield. Similarly, more respondents (38.4\%) reject this investment option among those who - wrongly - believe that investing in government papers entails a fee compared to those who understand that it is free of charge $(24.5 \%)$.

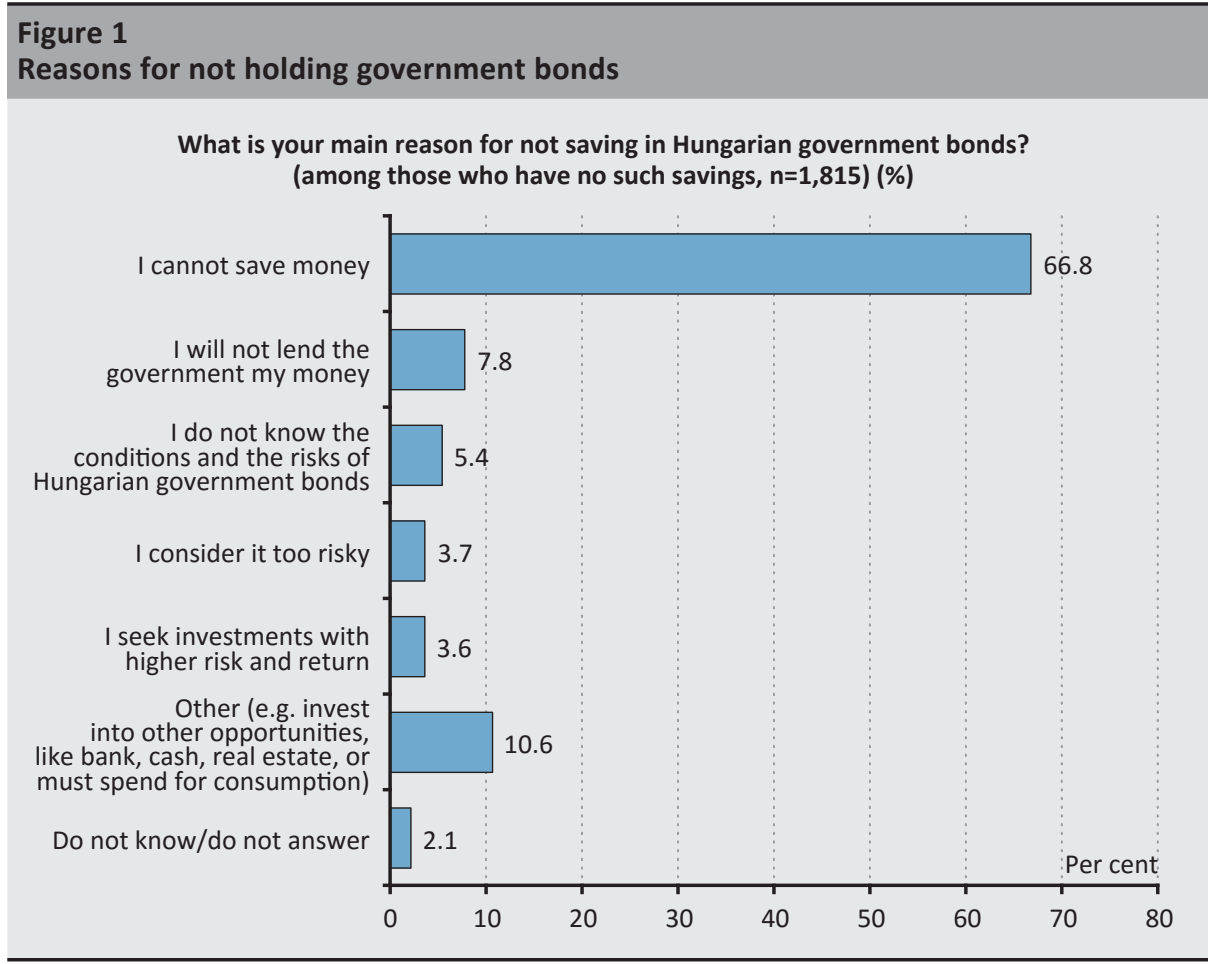

\subsection{How does the Hungarian population behave in investment matters?}

In the survey we also examined how respondents behaved in specific investment situations. According to the responses, 46.7 per cent of households would automatically invest their savings in bank deposits or government bonds, i.e. the two least risky, yet liquid investment options. This question aptly illustrates the difference between the genders: 52 per cent of women but only 42 per cent of men described 
themselves with this attitude. The behaviour of age groups in this regard is extremely diverse: only 35-38 per cent of the three age groups between 18 and 49 said that they would automatically invest their savings in bank deposits and government bonds, whereas 44 per cent of those aged 50-59 and 64 per cent of the 60+ age group would do the same. In other words, in the latter age groups, government bonds primarily compete with bank deposits, while for younger generations government papers should offer an attractive alternative to high-return but riskier investments. As regards education, there is a deep gulf between elementary education (eight grades) and the rest of the categories. 62 per cent of the former and 44 per cent of the latter invest their savings automatically in the two risk-free instruments. One important observation is that among the respondents with independent income, only 37.4 per cent of active workers would prefer to invest in bank deposits or government bonds, whereas this figure is 64.3 per cent among pensioners. From the perspective of income, the dispersion is not this significant.

The next two questions revealed that a fairly large portion of the population does not make reckless investment decisions. Only 8.3 per cent would be willing to gamble on "a sure bet". A significant minority, 19 per cent, leaves investment decisions to someone else, although a higher education level scaled back this attitude significantly. As regards "sure bets", the percentage of those preferring to leave the decision to others is as high as 19.5 per cent, while this attitude drops - in large increments with each education category - to 2.8 per cent among respondents with a college degree. Albeit with a smaller deviation, there is a clear relationship between leaving investment decisions to others and education level. There is a 6.5 percentage point difference between respondents with primary education (21.8\%) and respondents with a college/university degree (15.3\%). This percentage declines evenly with the increase in education level. At the same time, the overlap between the two forms of giving up decision-making is extremely small. Less than one tenth accepts "sure bets" at face value from among those who leave the decision to someone else, and even among those who declared they invest their money in "sure bets" without thinking, only 22 per cent would generally leave investment decisions to someone else (though the unconditional acceptance of someone else's suggestions practically means that the decision is made by someone else).

Household respondents were put into different decision-making situations to simulate the response of their demand for government bonds to various shocks. Respondents' horizon and propensity to save were not only measured by the extent to which they can/cannot save a portion of their current income and invest it in government papers, but they were also prompted to decide over what horizon would they be willing to save if they were given 1 million forints now. One quarter of the respondents could or would not set aside any savings, and nearly one third would not be able to wait even for a six-week retail Treasury bond to mature. Slightly more than 58 per cent of the respondents could invest an unexpected 


\section{Figure 2}

Decisions regarding the saving horizon

If you received HUF 1 million just now, how long would you save it for? (\%)

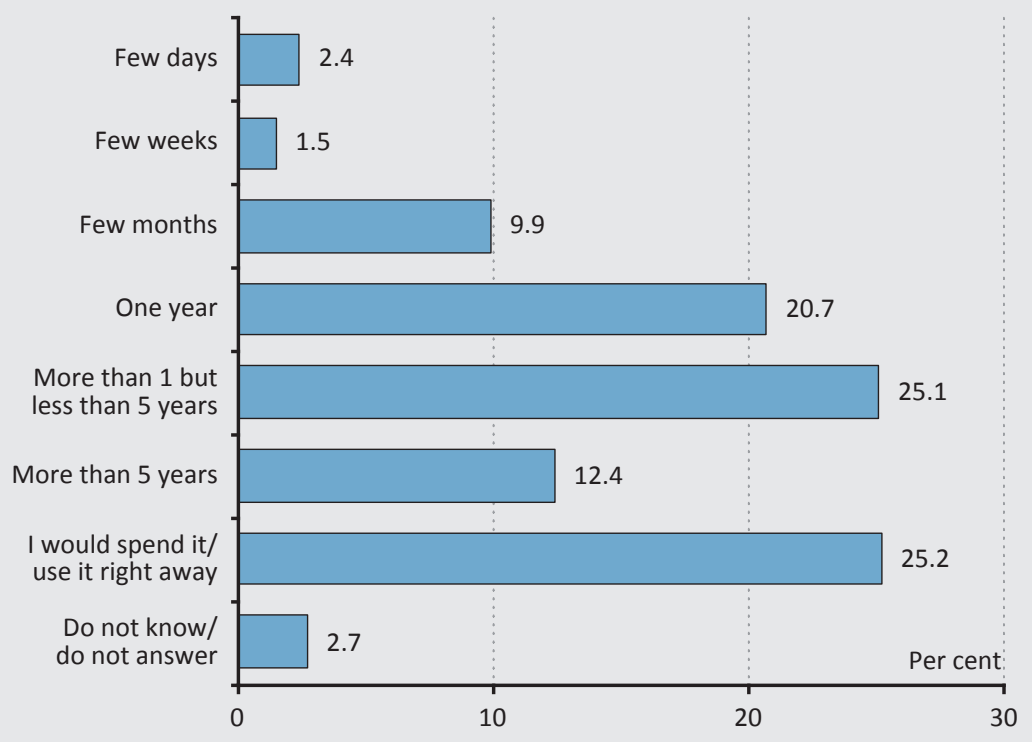

Figure 3

Households' preferences regarding savings instruments

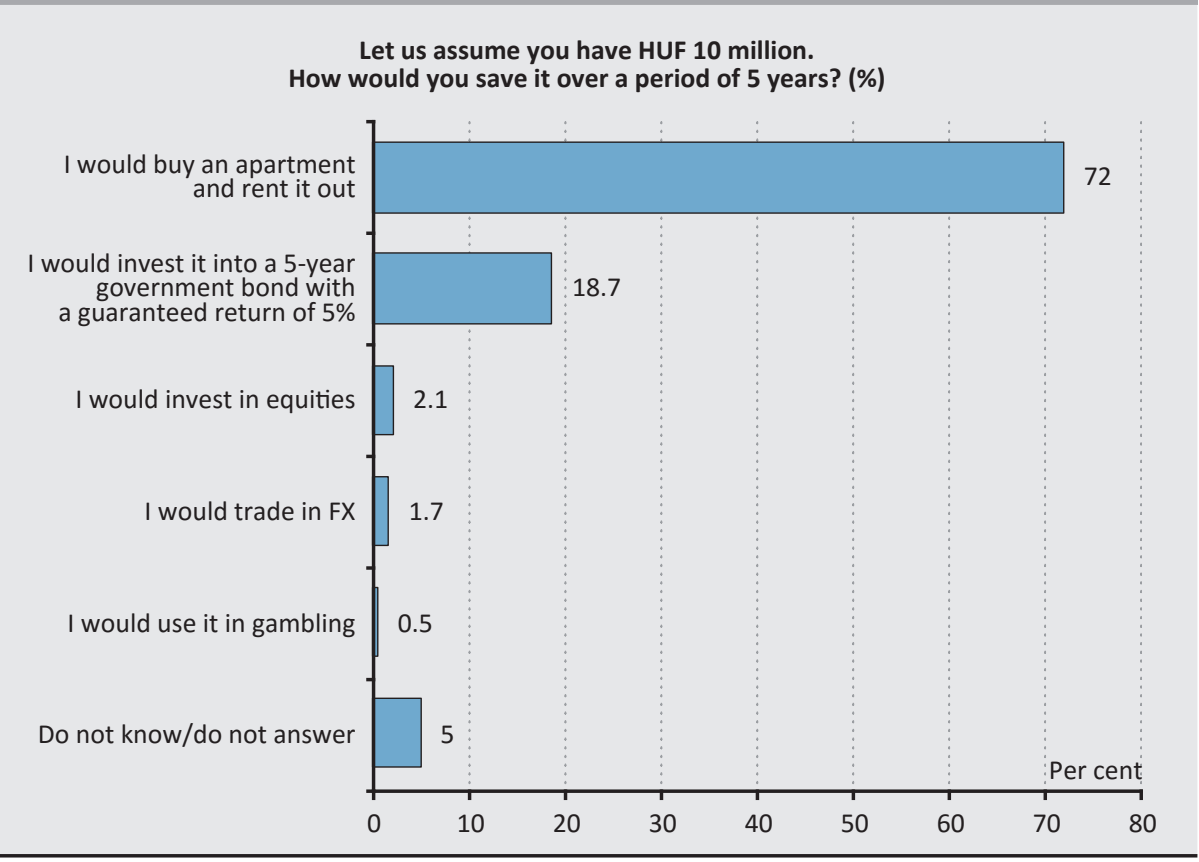


amount over and above their current income in a 1-year government security, from which only 12.4 per cent could get by without this amount in the long term (over 5 years). Deviations from this are fundamentally determined by income status and the related earning status. Those with higher income were more likely to be able to save the extra income over a longer horizon (Figure 2).

However, responses about a significant sum for investment, irrespective of the investment horizon, revealed that the vast majority (72\%) of the population would prefer to invest larger sums in real estate, which would not really require the same financial literacy and investment savviness as demanded by bond, equity and foreign exchange markets (Figure 3). Obviously, this may have been influenced by the surge observed in Hungarian real estate prices in 2016 and the parallel drop in bond yields. $^{2}$ That said, government bonds are still in second place with 18.7 per cent. Votes for the rest of the investment options were practically negligible. Once again, this reflects households' risk-averse and responsible saving behaviour.

We measured risk acceptance by asking household respondents about the level of risk they would be willing to take to abandon government bonds and their relatively safe return in the hope of higher yields. We asked whether they would be willing to sell a government bond worth HUF 1 million if they received a business offer which is just as likely to achieve a high return as generate a corresponding amount of loss. We asked this question for $+/-33$ per cent and +/-10 per cent profit/loss outcomes. Retail investors would be more open to accept a 10 per cent profit/loss, but even in this case, less than one third of the respondents would be willing to sell their government bond. Increased risk (and profit/loss outcomes) deters investors and encourages fewer respondents to take the risk. We found that the vast majority of households would be reluctant to give up safe returns in exchange for high promised yields entailing high risks. However, risk acceptance is higher among respondents with a higher income - those more likely to invest in government bonds -; they are more willing to combine their higher saving ability with a higher-risk portfolio. Whereas only 14-17 per cent of households with a per capita income of HUF 50,000 and HUF 100,000 would be willing to accept the $+/-33$ per cent outcome, and 23-28\% the +/-10 per cent outcome, 22 per cent and 32 per cent of respondent households with a per capita income above HUF 100,000 would be willing to sell the safe government paper and take the risk. Willingness to take risks declines with age in the case of both potential return outcomes. A distinction by gender confirms that men are more likely to be risk seekers, while women prefer safer investment portfolios.

\footnotetext{
${ }^{2}$ See the MNB's House Price Index at http://www.mnb.hu/en/statistics/statistical-data-and-information/ statistical-time-series/vi-prices/mnb-house-price-index and MNB - Average Government Securities Yields at Auctions http://www.mnb.hu/en/statistics/statistical-data-and-information/statistical-time-series/xiiisecurities-and-capital-market-data
} 
There is no complete overlap between the risk takers of the two profit levels; in other words, those who are willing to risk a smaller loss in the hope of a smaller profit would not necessarily take a greater risk for a higher return, and vice versa: those willing to take a greater risk for a higher return do not necessarily choose the riskier option in the smaller risk, smaller profit scenario. Only 41 per cent of those willing to take the 10 per cent profit/loss outcome were willing to take the 33 per cent profit/loss outcome. Moreover, only 58 per cent of those who would restructure their safe investments for a 33 per cent profit/loss outcome would do the same for a smaller profit/loss outcome. In a theoretical model that assumes a complete market and rational decision-makers, the decision-maker is risk neutral. ${ }^{3}$ The expected value of the specific decision-making situations of the opinion poll i.e. the respondent is as likely to win or lose - in all probability is zero. A rational, risk neutral participant should respond identically to the two different alternative investment opportunities (10 per cent and 33 per cent profit/loss outcomes) that still have the same expected value. This was not the case in this survey. In addition, the inconsistency of the response with the model is confirmed by the fact that one quarter to one fifth of the respondents would be willing to abandon an investment with a safe 5 per cent return for an investment with an expected value of zero.

\subsection{Imperfect information, herding effect}

The survey revealed that some of the population do not necessarily seek perfect information and rely on the opinions of others in investment decisions. 17.8 per cent of the respondents act intuitively, while 14.9 per cent follow the advice of close acquaintances, which could be viewed as a manifestation of the herding effect. Although financial advisors and banks are presumably well-informed in investment issues, consultation with such participants $(9.5 \%$ and $1.7 \%)$ can be regarded as a manifestation of the follower attitude. The only difference is that the participant followed relies on perfect - or at least, broad-based - information (Figure 4).

With respect to age distribution, the two extremes - ages 18-29 and the 50+ age group - are more likely to act on intuition ( $17 \%$ and $21 \%$, respectively), whereas the corresponding rates are 10-15 per cent in the age groups between 30 and 49 that exhibit a greater capacity to save. Interestingly, the rate of those obtaining information online is the highest in the latter age group (51 per cent and 42 per cent among respondents in their thirties and forties, respectively), even higher than with those aged 18-29, the $Y$ generation (40\%). The advice of close friends and acquaintances counts the most among the youngest respondents; one quarter of them primarily relies on such acquaintances for information. This rate is around 12-14 per cent in the older age groups. With respect to per capita income, the rate of those more likely to consult with financial advisors or banks or obtain

${ }^{3}$ For more detail about risk neutrality, see: Markowitz (1959), Merton (1972), Medvegyev (2009), Medvegyev (2010). 
information online increases with income. In other words, an increase in the saving rate improves the population's knowledge and scales back the herding effect.

It is a well-known phenomenon in group sociology that the decisions of individuals can be shaped by the ringleaders of their close acquaintances or a group. Respondents were asked whether the opinion of a close acquaintance was likely to change their investment preference. Nearly 17 per cent of the respondents answered probably or definitely; in their case the follower attitude is fairly apparent. In addition, more than a quarter of the respondents could not declare with certainty that they would not change their decisions in such situations. Consequently, it appears that a fairly large portion of households would potentially act on informal investment information if it is received from a close acquaintance; in other words, investment decisions are strongly influenced by group dynamics. In relation to this question, we cannot particularly identify based on specific group attributes who are more likely to listen to the opinions of others.

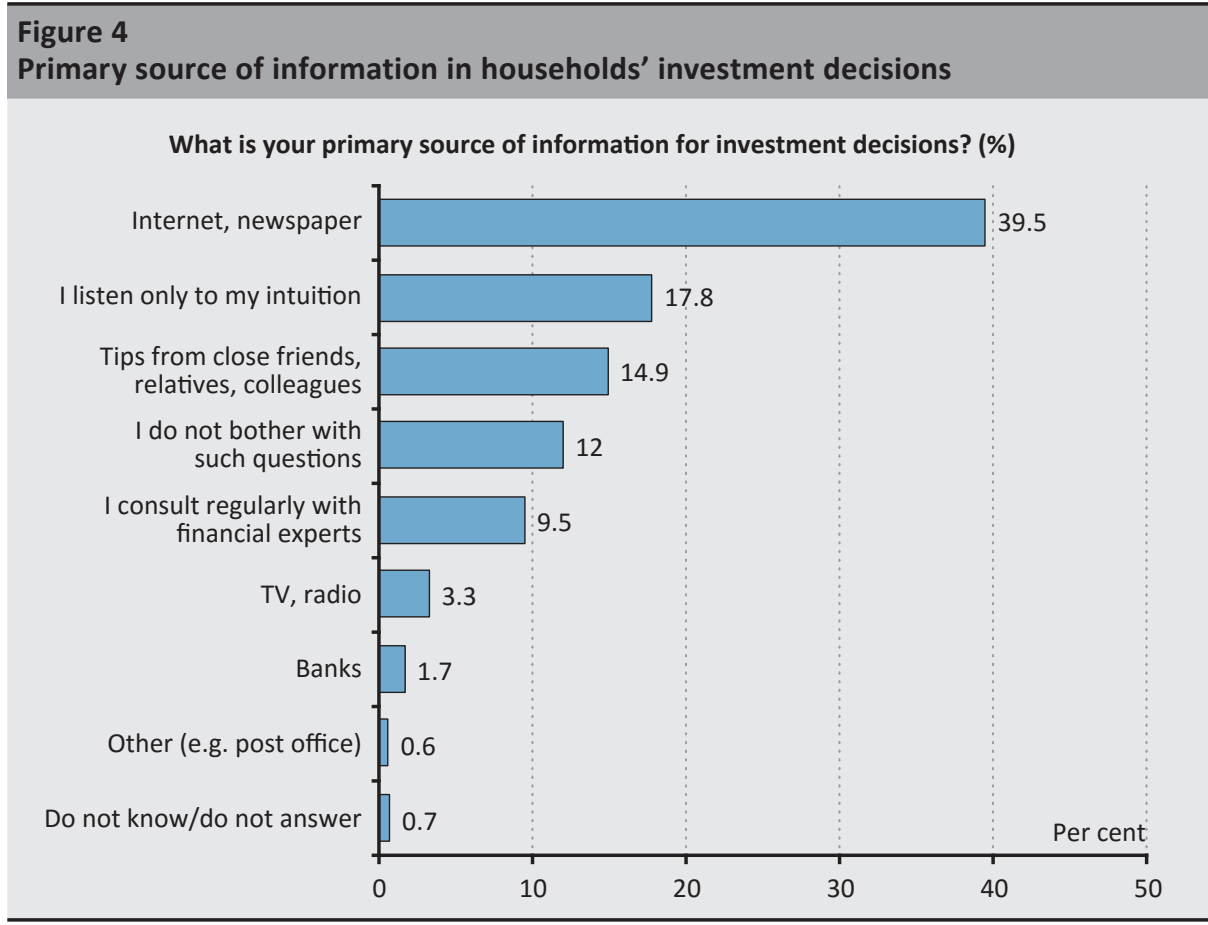

We formulated six questions to explore investors' response to an international market event or the action of an investment opinion leader (Figure 5). A potential downgrade of government debt would have a reasonably clear-cut result as it is directly related to the investment. In this scenario, a roughly identical percentage of retail investors ( $43.7 \%$ and $43 \%$ ) would choose to hold or sell their government 
papers. As regards international effects, households perceive more severe risks from a negative global economic shock than from a regional Greek insolvency. In the event of another Greek crisis, almost 60 per cent of the respondents would not adjust their Hungarian government bond position, whereas less than half of the respondents would stick with this decision in the case of a global downturn. Interestingly, some investors would be willing to increase their Hungarian government bond holdings in the case of both shocks, even in the event of a downgrade. We must assume that they either expect a hike in yields or view government bonds as a safe-haven asset. It is typically the younger, high-income category age group with (except for the Greek crisis) secondary or tertiary education that tend to overweight the decision to purchase. These are typical attributes of more informed investors.

To measure the herding effect, we asked respondents what they would do if a prominent investor, or the majority of market participants, or a "German" institutional investor - a paragon of reliability and prudence - started buying the government bonds. Although any one of these events is capable of mobilising the government bond market, apparently more than half of the population would not alter their government bond position at all. In response to purchases by the German participant and by Hungarian households, nearly one fifth of the respondents would

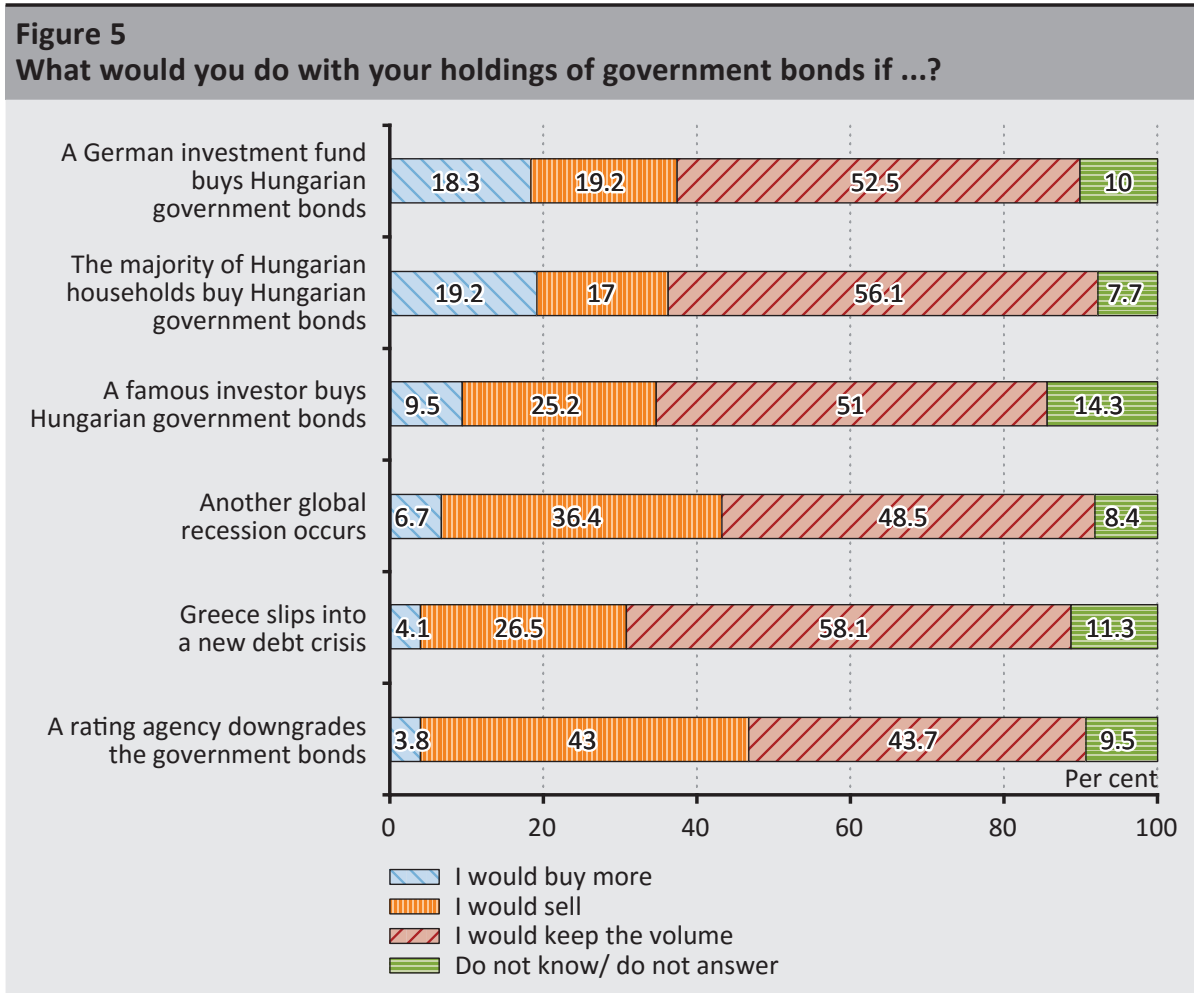


follow suit, but only 10 per cent would do the same if the purchases were made by a prominent investor. Parallel to this, one quarter/fifth of the respondents would do just the opposite: they would sell government papers in all three cases. It is hard to tell from the survey whether this reflects a rational, carefully assessed expectation about a downward shift in the yield curve or some other consideration. It is safe to say, however, that respondents with higher income and at least secondary, but in several cases (prominent investor, German institutional investor), tertiary education are far more likely than the average to follow the example of (an) opinion leader market participant(s). Interestingly, a higher percentage (15-30\%) of the respondents who consider themselves to be investors with an above-average performance follow the example of the above market participants.

Decisions do not overlap completely in the reactions to the three opinion leaders either. Only 26 per cent of those copying the decision of the German institutional investor copy the decision of the prominent investor as well, while 45.5 per cent also follow Hungarian households. 39 per cent of the respondents copying the decision of the prominent investor would also copy the action of Hungarian households, and 50 per cent of them would be motivated by the German investment fund too. 43 per cent of those copying Hungarian households would take the lead of the German investor, but only 20 per cent of them would be mobilised by the prominent investor's action. The overlap is far more significant in the case of those who would not alter their government bond position - the overlap here amounts to 70-75 per cent in all three cases. Respondents with an opposite attitude - willing to sell their papers contrary to the decision of opinion leaders - overlap at a rate of 50-65 per cent in each case. (Except for those responding to the prominent investor's intention to purchase by selling their papers, because they overlap at a rate of only 42 per cent with those selling their papers in response to Hungarian households' intention to purchase).

\subsection{The dimension of national sentiment}

Literature suggests that home bias or national sentiment also play an important role in the government bond market. During the survey we asked whether the respondents agreed that it is the patriotic duty of a Hungarian person to buy Hungarian government bonds. It appears that more than one quarter of household respondents agree with this opinion; accordingly, this sentiment is also a factor to be considered on the government bond market, yet another example that the factors explaining the behaviour of certain groups of retail investors go beyond return-maximising economic rationality. This opinion is extremely common (38\%) among respondents in the 60+ age group (including pensioners). An above-average percentage of respondents with a lower education level gave a similar answer (31 per cent of those with primary education and 29 per cent of those with trade school/vocational school degrees). With respect to income status, respondents from households with a per capita income of HUF 50-75 thousand represent this attitude at the highest rate (34\%). It should be noted that these groups generally represent peripheral groups of the 
government bond market and of household savings in general, with little or no savings at all. They are less pressured by having to meet their own expectations in practice and purchase Hungarian government papers out of patriotism.

As regards political preference, although seemingly a conspicuously high percentage of the respondents describing themselves as right-wing voters support this attitude, in reality this may rather reflect the prevailing pro-government/opposition status and relationship in October 2016. Indeed, of the opposition parties, 49.4 per cent of the supporters of the Hungarian Socialist Party (MSZP) agree with this patriotic duty - significantly exceeding even the 43.4 per cent rate measured among progovernment Fidesz-KDNP supporters -, whereas only 16.7 per cent of Jobbik supporters agreed with this statement, falling short of the rate observed among several smaller left-wing parties. We wish to emphasise, therefore, that political preferences can be measured even with this question of the survey, depending on the momentary political situation.

Interestingly, the percentage of those supporting the patriotic attitude is aboveaverage (30\%) even among those who respond to negative events (downgrade, global crisis, Greek crisis) by holding or buying government bonds (Figure 5). Moreover, more than 42 per cent of those with a preference for government bonds as opposed to other investment alternatives (Figure 3) also agreed with this attitude.

\section{Conclusions}

The practical result of the study is an opinion poll on Hungarian retail demand for government bonds assessed in the light of relevant theories. The profile of Hungarian households outlined in the study is a completely new result. First and foremost, this survey confirmed the most general social and economic characteristic; namely, that roughly two thirds of Hungarian society have no savings. A significant number of households have no savings at all; consequently, they are not involved or interested in investment issues. Households able to save typically have a short investment horizon. 58 per cent of these households would not even consider buying instruments with a maturity of over 1 year for saving purposes. Good news for government bond dealers, however, is that nearly 60 per cent of the households currently unable to save would invest in government bonds in the event of a future improvement in their income situation that allows them to save a portion of their income. On the other hand, wealthier Hungarian households prefer real estate to government bonds.

In the survey underlying the study, only 37.3 per cent of the respondents held investments. More than one third of these respondents (13.1\%), however, do not monitor the status of their investments, which cannot necessarily be considered rational behaviour on their part. 89 per cent of the respondents did not have government bond holdings, mostly because of their inability to save of course. 
Some of the respondents able to save, however, chose not to invest in government bonds due to a lack of information. Consequently, the complete market hypothesis does not fully hold true.

It was confirmed from several angles that households have limited information. Only 55 per cent of the respondents thought/knew that government bonds are backed by the state's payment guarantee. Although information improved with age, only about 60 per cent of the 40+ age-group were aware of the existence of the state guarantee. Education is a stronger determinant of information: 71 per cent of those with higher education knew about the state guarantee. Similarly, higher income which may be positively related to education and the ability to save - also brought greater knowledge about investment issues. Likewise, respondents were not fully informed about tax allowances and yields.

At the same time, the lack of information should not be always viewed as evidence of an incomplete market and a non-rational decision-making situation. The survey revealed that some of the population do not necessarily seek perfect information, and rely on the opinions of others in investment decisions. The advice of close friends and acquaintances is predominant among the youngest respondents; 25 per cent of them primarily rely on such acquaintances for information. With respect to per capita income, the rate of those more likely to consult with financial advisors or banks or obtain information online increases with income. In other words, an increase in the ability to save improves the population's knowledge and scales back the herding effect. The identified opinion-follower groups, in turn, can be a new target for the sale of government bonds, through which opinion followers could be included more efficiently in the retail demand for government bonds.

Based on various questions probing respondents' attitudes and preferences, 90 per cent of Hungarian households seek safety in investments and would not make irresponsible decisions if given an opportunity to save. We measured risk acceptance by asking household respondents about the level of risk they would be willing to take to abandon government bonds and their relatively safe return in the hope of higher yields. We found that the vast majority of households would be reluctant to give up safe returns in exchange for high promised yields entailing high risks. This also benefits the sale of government bonds in view of the strong loyalty of demand towards low-return but safe financial products. Interestingly, risk acceptance is higher among respondents with higher income - those investing the most in government bonds -; they are more willing to combine their higher ability to save with a higher-risk portfolio.

In a small and open economy such as Hungary and in the riskier investment environment of the forint market, it was worth examining households' response to international market effects. We formulated six questions to simulate Hungarian 
retail investors' response to important international market events or to the action of an investment opinion leader. In the event of a downgrade of Hungarian sovereign bonds, a roughly identical percentage of retail investors would choose to hold or sell their government papers. As regards international effects, households associate more severe risks with a negative global economic shock than with a regional Greek insolvency. In the event of another Greek crisis, almost 60 per cent of the respondents would not adjust their Hungarian government bond position, whereas less than half of the respondents would stick with this decision in the case of a global downturn. In order to measure the herding effect, we asked respondents what they would do if a prominent investor, or the majority of market participants, or a "German" institutional investor - a paragon of reliability and prudence - would start buying the government bonds. Although any one of these events is capable of mobilising the government bond market, apparently more than half of the population would not alter their government bond position at all. In response to purchases by the German participant and by Hungarian households, nearly one fifth of the respondents would follow suit, but only 10 per cent would do the same if the purchases were made by a prominent investor. We may conclude, therefore, that the domestic retail segment of the Hungarian government bond market is a stabilising factor for Hungarian government debt management. Accordingly, a greater share of Hungarian retail investors increases the shock resilience of the Hungarian government bond market and mitigates its exposure to financial speculation.

The survey revealed that political considerations and political sentiment are also present in the Hungarian government bond market. Some respondent groups specifically cited political/sentimental reasons - instead of economic considerations - for not buying Hungarian government papers. For the most part, those rejecting government bonds on political grounds are anti-government voters. However, the opposite attitude - home bias - could also be observed in the securities market. Based on our results, national sentiment, home bias and patriotism also play an important role in the government bond market. More than one quarter of household respondents agree with the opinion that a Hungarian person has a patriotic duty to buy Hungarian government bonds, yet another example that the factors explaining the behaviour of certain groups of retail investors go beyond return-maximising economic rationality.

An ancillary result of the survey that may be the subject of further research is the following: It can be assumed that households do not have a textbook interpretation of risks. They consider real estate and gold to be less risky investment options than government bonds. There is a strong relationship between the perception of riskiness for various investment instruments and awareness of the state guarantee. More than two thirds of the respondents who considered government bonds the riskiest investment instrument did not know about the state guarantee. 


\section{References}

Amadi, A. A. (2004): Does familiarity breed investment? An empirical analysis of foreign equity holdings. An Empirical Analysis of Foreign Equity Holdings, April 6.

Anderson, C. W. - Fedenia, M. - Hirschey, M. - Skiba, H. (2011): Cultural influences on home bias, and international diversification by institutional investors. Journal of Banking \& Finance, 35(4): 916-934. https://doi.org/10.1016/j.jbankfin.2010.09.006

Arnott, R. D. - Chaves, D. B. (2012): Demographic changes, financial markets, and the economy. Financial Analysts Journal, 68(1): 23-46. https://doi.org/10.2469/faj.v68.n1.4

Baker, M. - Wurgler, J. (2006): Investor sentiment and the cross-section of stock returns. The Journal of Finance, 61(4): 1645-1680. https://doi.org/10.1111/j.1540-6261.2006.00885.x

Bakshi, G. S. - Chen, Z. (1994): Baby boom, population aging, and capital markets. Journal of Business, Volume 67, Issue 2, April: 165-202. https://doi.org/10.1086/296629

Barber, B. M. - Odean, T. (2001): Boys will be boys: Gender, overconfidence, and common stock investment. Quarterly Journal of Economics, Volume 116, Issue 1, 1 February: 261292. https://doi.org/10.1162/003355301556400

Beugelsdijk, S. - Frijns, B. (2010): A cultural explanation of the foreign bias in international asset allocation. Journal of Banking \& Finance, 34(9): 2121-2131.

https://doi.org/10.1016/j.jbankfin.2010.01.020

Brown, K. C. - Harlow, W. V. - Tinic, S. M. (1988): Risk aversion, uncertain information, and market efficiency. Journal of Financial Economics, 22(2): 355-385.

https://doi.org/10.1016/0304-405X(88)90075-X

Coval, J. D. - Moskowitz, T. J. (1999): Home bias at home: Local equity preference in domestic portfolios. Journal of Finance, 54(6): 2045-2073. https://doi.org/10.1111/00221082.00181

Davis, E. P. - Li, C. (2003): Demographics and financial asset prices in the major industrial economies. ResearchGate. Online: https://www.researchgate.net/publication/4799298. Downloaded: 14 August 2016.

Ferreira, M. A. - Matos, P. (2008): The colors of investors' money: The role of institutional investors around the world. Journal of Financial Economics, 88(3): 499-533.

https://doi.org/10.1016/j.jfineco.2007.07.003

Grinblatt, M. - Keloharju, M. (2001): How distance, language, and culture influence stockholdings and trades. Journal of Finance, 56(3): 1053-1073.

https://doi.org/10.1111/0022-1082.00355 
Guiso, L. - Sapienza, P. - Zingales, L. (2004): Cultural biases in economic exchange. National Bureau of Economic Research, Working Paper No. 11005. https://doi.org/10.3386/w11005

Harrington Jr, J. E. (1993): Economic policy, economic performance, and elections. The American Economic Review, 83(1): 27-42.

Hofstede, G. (2001): Culture's consequences: Comparing values, behaviors, institutions and organizations across nations. Sage Publications

Huang, T. - Wu, F. - Yu, J. - Zhang, B. (2015): International political risk and government bond pricing. Journal of Banking \& Finance, 55: 393-405. https://doi.org/10.1016/ j.jbankfin.2014.08.003

Kang, H. C. - Lee, D. W. - Park, K. S. (2010): Does the difference in valuation between domestic and foreign investors help explain their distinct holdings of domestic stocks? Journal of Banking \& Finance, 34(12): 2886-2896. https://doi.org/10.1016/j.jbankfin.2009.11.020

Kang, J. K. (1997): Why is there a home bias? An analysis of foreign portfolio equity ownership in Japan. Journal of Financial Economics, 46(1): 3-28. https://doi.org/10.1016/S0304405X(97)00023-8

Karlsson, A. - Nordén, L. (2007): Home sweet home: Home bias and international diversification among individual investors. Journal of Banking \& Finance, 31(2): 317-333. https://doi.org/10.1016/j.jbankfin.2006.04.005

Kothari, S. P. - Shanken, J. (1997): Book-to-market, dividend yield, and expected market returns: A time-series analysis. Journal of Financial Economics, 44(2): 169-203. https://doi.org/10.1016/S0304-405X(97)00002-0

Laborda, R. - Olmo, J. (2014): Investor sentiment and bond risk premia. Journal of Financial Markets, 18: 206-233. https://doi.org/10.1016/j.finmar.2013.05.008

Legg Mason (2015): The secret lives of investors: Lessons from behavioral finance. Online: https://www.leggmason.com/content/dam/legg-mason/documents/en/insights-andeducation/brochure/lessons-from-behavioral-finance.pdf. Downloaded: 14 August 2016

Markowitz, H.M. (1959): Portfolio Selection: Efficient Diversification of Investments. New York: John Wiley \& Sons. (2nd ed. Basil Blackwell, 1991)

Martell, R. (2008): Understanding Common Factors in Domestic and International Bond Spreads. Review of Finance, 12(2): 365-389. https://doi.org/10.1093/rof/rfn004

Medvegyev, P. (2009): A származtatott termékek árazása és annak problémái az egyensúlyelmélet szempontjából (Pricing of derivative products and related problems in terms of equilibrium theory). Közgazdasági Szemle, 56(6): 769-789. 
Medvegyev, P. (2010): A hasznossági függvények és a kockázatsemleges mérték (Utility functions and risk-neutral measures). Hitelintézeti Szemle, 9(6): 487-496.

Merton, R. (1972): An analytic derivation of the efficient portfolio frontier. Journal of Financial and Quantitative Analysis, 7(4): 1851-1872. https://doi.org/10.2307/2329621

Modigliani, F. - Brumberg, R. (1954): Utility analysis and the consumption function: An interpretation of cross-section data. In: Kurihara, K. K. (ed.) Post Keynesian Economics. New Brunswick: Ruthers University Press. pp. 383-436.

Moser, C. (2007): The impact of political risk on sovereign bond spreads-evidence from Latin America. Online: https://www.econstor.eu/bitstream/10419/19887/1/Moser_revised.pdf. Downloaded: 14 August 2016

Neal, R. - Wheatley, S. M. (1998): Do measures of investor sentiment predict returns? Journal of Financial and Quantitative Analysis, 33(04): 523-547. https://doi.org/10.2307/2331130

Pantzalis, C. - Stangeland, D. A. - Turtle, H. J. (2000): Political elections and the resolution of uncertainty: the international evidence. Journal of Banking \& Finance, 24(10): 1575-1604. https://doi.org/10.1016/S0378-4266(99)00093-X

Šević, A. - Brawn, D. (2015): Do demographic changes matter? A cross-country perspective. Journal of Multinational Financial Management, 30: 36-61.

\section{Annex}

Questions asked in the opinion poll

1. In your opinion, which of the following is the least risky investment?
1) Share
2) Government bond
3) Corporate bond
4) Gold
5) Real estate

2. In your opinion, which of the following is the riskiest investment?
1) Share
2) Government bond
3) Corporate bond
4) Gold
5) Real estate 
3. In your opinion, does the state guarantee the repayment of the principal in government bonds?
1) Yes
2) No
3) Do not know/no response

4. In your opinion, is there a tax or contribution allowance on government bond yields?

1) Yes

2) No

3) Do not know/no response

5. In your opinion, do bank deposits or government bonds have higher returns?
1) Bank deposits
2) Government bonds
3) Do not know/no response

6. In your opinion, how much does it cost to subscribe government bonds?
1) Free of charge
2) $0.5 \%$ of the transaction value
3) $1 \%$ of the transaction value
4) Do not know/no response

7. Do you have any savings in a Hungarian government paper? (pick the most appropriate answer)

1) I do not have any savings.

2) No, because I seek high-risk/high-return investments.

3) No, because I am not familiar with the conditions and risks of Hungarian government bonds.

4) No, because I consider it too risky.

5) No, because I refuse to loan any money to this government.

6) Yes, because it is a safe and risk-free investment option.

7) Yes, because I am not very familiar with any other investment options.

8) Do not know/no response

8. Do you have any savings in Hungarian government bonds?
1) Yes
2) No
3) No response 
9. Is the following statement true for your saving decisions?

If I have a chance to save, I automatically invest in bank deposits or government bonds. I do not monitor yields and conditions.

1) Yes

2) No

3) Do not know/no response

10. Is the following statement true for your saving decisions?

If I receive a sure bet, I invest my money in it immediately.

1) Yes

2) No

3) Do not know/no response

11. Is the following statement true for your saving decisions?

Usually I leave the decision to others.
1) Yes
2) No
3) Do not know/no response

12. For what purpose do you hold your savings in Hungarian bonds? (multiple answers are acceptable)

1) I do not know yet for what purpose, but I set aside savings.

2) For real estate purchase, house construction, some more expensive consumer durable or a car.

3) For the purposes of my enterprise.

4) For financing / leaving inheritance for my children/grandchildren.

5) For repaying my debt.

6) For my old age, for my retirement.

7) For travelling.

8) For unexpected household expenses.

9) No response 
13. If you do not hold any savings in Hungarian government bonds, why? (multiple answers are acceptable)

1) I have no money to save.

2) I have no confidence in the solvency of the Hungarian state.

3) I refuse to loan any money to these politicians.

4) Hungarian government bonds do not pay sufficient yields.

5) Government papers are boring; I like to take risks.

6) I am not aware that I can save my money in Hungarian government papers.

7) I would rather keep my money in my bank account.

8) Do not know/no response

14. How often do you check the status of your investments?

1) More than once a day

2) Once a day

3) Once a week

4) Once a month

5) Less than once a month

6) I do not check their status at all

7) I have no investments.

8) Do not know/no response

15. To what extent would you describe yourself as a good investor compared to the average?

1) Above-average

2) Average

3) Below-average

4) Do not know/no response

16. Which statement describes your view of life and investor attitude the best?

1) I am not interested in investment issues; money is irrelevant in my life.

2) High risks are to be avoided in investments. The guaranteed repayment of the principal is of primary importance; yields are secondary.

3) It is necessary to take risks in life. I have an understanding of and therefore I also undertake riskier investments.

4) I seek riskier investments that will allow me to get rich faster.

5) Do not know/no response 
17. How do you obtain your information in financial matters?

1) I regularly consult with a financial advisor

2) From the internet and newspapers

3) My close friends, relatives or co-workers tip me off

4) I only act on my own intuition

5) I am not interested in these issues

6) Do not know/no response

18. Consider that you have 1 million forints in government bonds with a safe $5 \%$ annual return. You get a business offer, in which you are as likely to increase your capital by one third or lose one third of your capital. Would you sell your government bond in order to invest in this business opportunity?
1) Yes
2) No
3) Do not know/no response

19. Consider that you have 1 million forints in government bonds with a safe $5 \%$ annual return. You get a business offer, in which you are as likely to increase your capital by one and a half or lose half of your capital. Would you sell your government bond in order to invest in this business opportunity?
1) Yes
2) No
3) Do not know/no response

20. Consider that you have 1 million forints in government bonds with a safe $5 \%$ annual return. You get a business offer, in which you are as likely to increase your capital by $10 \%$ or lose $10 \%$ of your capital. Would you sell your government bond in order to invest in this business opportunity?
1) Yes
2) No
3) Do not know/no response

21. How would you respond if a credit rating agency downgraded the government security held by you?

1) I would buy even more bonds in view of the expected increase in yields.

2) I would sell all of my government bonds immediately and would invest the funds in a safer instrument.

3) I would sell some of my government bonds and invest in another instrument to diversify the risk.

4) I would continue to hold the same amount of government bonds.

5) Do not know/no response 
22. Consider that you have a Hungarian government bond maturing in two years that is worth HUF 1 million. What would you do with your Hungarian government bonds if Greece slipped into another debt crisis?

1) I would buy some more.

2) I would sell my existing securities.

3) I would hold my existing securities (neither buy, nor sell)

4) Do not know/no response

23. Consider that you have a Hungarian government bond maturing in two years that is worth HUF 1 million. What would you do with your Hungarian government bonds in the case of another global economic downturn?

1) I would buy some more.

2) I would sell my existing securities.

3) I would hold my existing securities (neither buy, nor sell)

4) Do not know/no response

24. Consider that you have a Hungarian government bond maturing in two years that is worth HUF 1 million. You have read that a prominent investor has started to buy Hungarian bonds. What would you do with your Hungarian government bonds?

1) I would buy some more.

2) I would sell my existing securities.

3) I would hold my existing securities (neither buy, nor sell)

4) Do not know/no response

25. Consider that you have a Hungarian government bond maturing in two years that is worth HUF 1 million. You have read that most Hungarian households are purchasing Hungarian government bonds. What would you do with your Hungarian government bonds?

1) I would buy some more.

2) I would sell my existing securities.

3) I would hold my existing securities (neither buy, nor sell)

4) Do not know/no response

26. Consider that you have a Hungarian government bond maturing in two years that is worth HUF 1 million. You have read that a German investment fund has started to purchase Hungarian government bonds. What would you do with your Hungarian government bonds?

1) I would buy some more.

2) I would sell my existing securities.

3) I would hold my existing securities (neither buy, nor sell)

4) Do not know/no response 
27. What would you do if a close acquaintance explained that he had a completely opposite opinion in an investment matter?

1) I would change my investment decision, agreeing with his opinion.

2) I would stick with my own decision and would try to validate that it is correct.

3) It would crush me, the criticism would hurt my feelings and make me confused.

4) Do not know/no response

28. Do you agree that it is the patriotic duty of a Hungarian person to buy Hungarian government bonds?

1) I agree

2) I do not agree

4) Do not know/no response

29. Which form of saving would you prefer if you had to make a decision about half of your existing funds (or, for lack of any funds, about your 6-monthly income)?

1) I would invest my funds in 5-year government bonds with a safe $5 \%$ return.

2) I would purchase real estate (participate in a real estate purchase transaction) and sublet the real estate, undertaking the risk of a potential real estate market devaluation, the payment of periodical renovation expenses and tenants' potential payment delays in the next 5 years.

3) I would invest my funds in stocks: according to the current outlook, stock prices will either double or halve in the next 5 years.

4) I would engage in high-leverage foreign exchange trading. If I make a loss, my debt will exceed even my existing funds - but if I make a profit, I will increase my funds tenfold. According to the outlook, a currency is as likely to weaken as it is to strengthen.

5) I would join a poker game or engage in gambling or sports betting where I either lose all the money for good or increase my money by a hundredfold.

6) Do not know/no response 